University of Warwick institutional repository: http://go.warwick.ac.uk/wrap This paper is made available online in accordance with publisher policies. Please scroll down to view the document itself. Please refer to the repository record for this item and our policy information available from the repository home page for further information.

To see the final version of this paper please visit the publisher's website. Access to the published version may require a subscription.

Author(s): Richard Aldrich

Article Title: The UK-US intelligence alliance in 1975: Economies, evaluations and explanations

Year of publication: 2006

Link to published version:

http://dx.doi.org/10.1080/02684520600885681

Publisher statement: None 


\section{The UK-US Intelligence Alliance in 1975: \\ Economies, Evaluations and Explanations}

\section{Richard J. Aldrich}

The importance of the related subjects of intelligence and defence to the maintenance of the broader Anglo-American relationship during second half of the twentieth century has been frequently remarked upon, and indeed often celebrated. ${ }^{1}$ Christopher Andrew has observed that: 'Ever since the Second World War, the Anglo-American intelligence alliance has remained the most special and most secret part of the special relationship'. David Reynolds, commenting on relations between the UK and the US since 1945, has argued that it is 'at the heart of what makes the Anglo-American tie so different from other alliances'. In his study of Anglo-American relations since 1963 John Dumbrell devotes a substantial section to UKUS intelligence and observes that together with nuclear information, the 'intimate intermeshing of US and British intelligence ... formed the essence and beating heart of the Cold War "special relationship" '. ${ }^{2}$

Inevitably, we know less about the Anglo-American intelligence relationship during the period after Vietnam. ${ }^{3}$ Despite recent changes in declassification regimes and existence of the Freedom of Information Act on both sides of the Atlantic, most files remain closed for thirty years. Moreover, intelligence liaison is a sensitive subject and not one likely to attract early release. The benchmarks of declassification have, if anything tightened during the last few years in response to the events of 9/11. The National Archives in Washington has seen a remarkable process in which some 55,000 rather elderly documents, notable only for their extreme dullness, have been reclassified in the name of national security. ${ }^{4}$ In the UK, a Freedom of Information Act has resulted in an uneven situation, with some department of state attempting to be helpful, while others are seemingly flouting the requirements of the legislation. ${ }^{5}$ In the UK, alongside these general problems, there have been other archival issues more specifically related to defence and intelligence. ${ }^{6}$ 
Notwithstanding these impediments, intelligence during the second half of the Cold War is a subject of real interest because of the changing nature of the Anglo-American special relationship. Always a partnership of unequals, these allies became more unequal as the UK continued its 'long retreat' from its world role, beset by a seemingly endless process of economic decline. In the late 1960s Harold Wilson's government was forced to embark on the famous withdrawal from east of Suez. ${ }^{7}$ In February 1968, in the wake of this withdrawal, and having just failed in his bid to enter the EEC, a demoralised Harold Wilson visited Lyndon Johnson in Washington. The State Department drew up a brief in preparation for the Wilson visit, entitled 'What now for Britain?' asking what was left of the alliance. The report was surprisingly positive, arguing that the twin fields intelligence and nuclear weapons were 'concrete proof' that these two countries remained each other's 'favoured partner'. They exchanged information that they shared with no one else and there was a division of labour, which meant that on some subjects 'each nation is dependent for its intelligence mainly on the other. ${ }^{8}$

However, 1968 was not the end-point for British decline. Ahead lay Edward Heath's troubled premiership (1970-74) and the dark days of the three-day week. Each rocky landmark along the road of retreat was accompanied by predictions that the UK might soon be a European power only, or that the UK's entry into Europe would soon see 'specialness' subsumed within wider transatlantic arrangements. By the time Harold Wilson returned to office in 1974, the UK was in the middle of a severe economic crisis, triggering a major defence review led by Defence Secretary Roy Mason, which rolled on until 1976. The advent of James Callaghan in 1976 brought a visit from the IMF and there seemed no end to climate of perpetual economic gloom and retrenchment. The events of the mid-1970s prompted policy-makers to undertake a searching review of defence priorities and to confront difficult choices. As a result, officials were forced to cast up general evaluations and explanations of the fundamentals of their policy in a way that they were perhaps not accustomed to do. Accordingly, the documents generated by these processes are rarely uninteresting. 
Specifically, recently declassified material generated by the mid-1970s Defence Review casts interesting light on relations between the Foreign and Commonwealth Office (FCO) and Ministry of Defence (MOD), on the Defence Intelligence Staff and ultimately on the place of intelligence in Anglo-American relations. In July 1975, as part of the ongoing process of Defence Review, Sir Michael Cary, the Permanent Under Secretary at the MoD, wrote to his opposite number in the FCO, requesting comments and suggestions regarding the overall management of the MOD. This was only natural given that many FCO departments had increasing engagement with their defence counterparts on matters such as arms control or NATO planning. Accordingly, a general call went out to all FCO departments for their opinions. ${ }^{9}$

Diplomatic commentary on the MOD poured forth and James Cable, Head of the FCO's Planning Staff, set the tone. He identified several related issues. First, he considered that the MOD had not achieved genuine inter-service integration and maintained up to six separate hierarchies. ${ }^{10}$ Second, he was conscious that in areas such as European defence procurement and arms control, the diplomats and the military were not making joined-up policy. Third, he felt that too much effort was still being devoted to 'intelligence and analysis concerning areas of the world where the British Armed Forces are never likely to play a significant part.' Indeed, during a recent joint long-term planning exercise which aimed to forecast the international situation in 1985 the MOD had been reluctant to accept the prediction of the diplomats that by then the UK 'would have little interest in anything outside Europe'. He added that while the diplomats often joked that the MOD would rather concern itself with foreign policy than with military matters, nevertheless this observation did 'conceal grain of truth'. ${ }^{11}$

The most sustained criticisms were directed at the scope and scale of activities undertaken by the Defence Intelligence Staff (DIS), especially the extent to which it was still gathering intelligence that was predicated on a continued world role. The MOD certainly maintained a large intelligence gathering and analytical apparatus - and also boasted a Directorate of Economic Intelligence. Alistair Hunter in the Western European Department offered the 
example of Cambodia to illustrate the way in which MOD was directing intelligence effort to areas of the world which 'were now unimportant to us'. He continued:

I remember, in April 1970, being required by the DIS to devote (along with others) an infinite number of man hours trying to modify their theory that, after the fall of Sihanouk, the Khmer Rouge would take over Cambodia in a matter of days. The FCO view was that the Khmer Rouge were unlikely ever to be a serious threat. The correct assessment would have been mid-way between the MOD and FCO views: but it mattered very little, either way, to British foreign or defence policy. Nevertheless, so far as I am aware, the section of DIS in question, even these days, is staffed at the same level. ${ }^{12}$

Officials in other departments added comments in a similar vein. Some noted that the MOD were busy 'collecting more intelligence about China than we can possibly need'. Others thought that the MOD produced more detailed and voluminous economic intelligence than was necessary and wondered why this economic analysis work was not located 'elsewhere in Whitehall. ${ }^{13}$

David Wright, also from the Western European Department, complained about the proliferation of defence officials that seem to be duplicating the functions of others and again focused on what he called the MOD's 'excessive allocation of manpower to intelligence and analytical work'. Underlying this sentiment was a concern that the MOD's considerable appetite for intelligence often drew it into areas that were political rather than military, and prompted defence officials to engage with subjects on which he thought them ill-equipped to comment. As an example, Wright singled out the matter of Current Intelligence Group Meetings [CIG meetings], which constituted the largely geographically focused sub-groups of the Joint Intelligence Committee:

Most CIG meetings which I attend either take place because the MOD alone among the Whitehall departments considers it necessary to have a paper circulated on the subject or, when other Whitehall Department think it 
necessary, the MOD are represented by serried ranks of advisers in comparison with the presence of one FCO Desk Officer. I have faced particular problems over MOD requesting the production of papers when there is nothing useful to say. Furthermore, when asked to produce their own draft, it is jejune to the point of embarrassment. This places the FCO in a difficult position. We are obliged to spend time and energy improving and correcting a draft which we never thought necessary in the first place. ${ }^{14}$

Wright's colleague, Sophie Lambert, the desk officer for Berlin, expressed similar sentiments, arguing that MOD's political and intelligence analysis work 'appears to me to be both wasteful and erratic'. ${ }^{15}$

FCO-MOD tensions over intelligence existed at the regional level as well as in Whitehall. In the UK Embassy in Bonn, Reginald Hibbert chaired the local Joint Intelligence Committee (Germany) and struggled to keep a watch on a vast empire of military intelligence activities that included the exciting escapades of the BRIXMIS mission in East Germany. Hibbert would sometimes commission JIC Germany reports in order draw out the attitudes of his military colleagues on these awkward matters. The military and the diplomats rarely saw eye to eye on the levels of risk that attended these operations. ${ }^{16}$ David Beattie offered, en passant, a fascinating comment on the Middle East, suggesting that here again, a key function of the regional JIC was to serve as a local interlocutor between the diplomats and the military. His own recent experience in Cyprus suggested that the main purpose of having a local joint intelligence group was not so much to generate fresh intelligence but instead 'to give the military firm political direction'. He continued:

Since they have their own communications, they [the military] cannot otherwise be prevented from firing off their own political judgements to the MOD which are sometimes wildly in error. In Nicosia, I used to draft once a week an Intelligence Summary which was usually little more than a resume of Chancery reporting over the past week. This was telegraphed out to the bases, and the Counsellor of the High Commission would then set out once a week to the bases 
in order to preside over the meeting of JIG (Cyprus). One or two commas might be removed from my draft by the military and then replaced after furious argument and the thing would, as a rule, be despatched to London as drafted in the High Commission. It was all, no doubt, a great waste to the Counsellors' time, and of helicopter fuel: but if one considered the time that might have been wasted in Whitehall by clashes of opinion between the MOD and FCO, the effort was probably worth it. ${ }^{17}$

Of course, some of these comments reflected the undoubted pleasures of a bit of interdepartmental back-biting, but others reflected longer-term tensions over intelligence between the MOD and FCO that could be traced back as far as the Second World War. It is likely that they also reflected several structural oddities within the UK intelligence system of which even the FCO officials themselves were perhaps not fully aware.

First, the Defence Intelligence Staff had been created some ten years earlier, in 1964, nursed along by the inter-service evangelist, General Kenneth Strong. Strong, who enjoyed great standing by virtue of his excellent relations with Washington had headed the only genuinely inter-service intelligence organisation in Whitehall after 1945, the Joint Intelligence Bureau (JIB). However, it had been possible to create his bureau only because it consisted of curious bits and pieces, including topographical intelligence, that no-one else much wanted. His subsequent struggle to merge service intelligence departments to create the Defence Intelligence Staff (DIS) took twenty years and the inter-service compromises that led to its creation in 1964 involved some considerable duplication. This was reflected in other parts of the MOD. ${ }^{18}$

Second, although the Joint Intelligence Committee (JIC) was a much-vaunted aspect of the UK intelligence system, it had been systematically starved of support. The JIC, which resided in the Cabinet Office together with its subordinate elements and assessments staff, remained remarkably small. Therefore, in terms of professional analytical capability, DIS was the Whitehall giant. This reflected its approach as well as its size, since the DIS boasted dedicated long-term analysts, while those serving the JIC were usually temporaries serving 
out a two-year assignment. The JIC had failed to follow its American opposite numbers in creating a category of professional analysts within the Whitehall system. The extent to which the UK central intelligence machine was 'assessment-lite' was an odd quirk which and number of people have commented on down the years, including the Franks enquiry on the Falklands in $1983 .{ }^{19}$ In 2004, Lord Butler felt the need to revisit the same territory in his enquiry into intelligence on Iraqi WMD and made the same observations. ${ }^{20}$

However, the most substantial explanatory factor here - and one that was largely hidden was Anglo-American intelligence relations. The sustained critique of DIS that poured forth from various quarters in the FCO prompted a lengthy rejoinder from Derek Tonkin in the FCO's Permanent Under Secretary's Department (PUSD). Tonkin sought both to reassure his colleagues, and to explain the mysteries of the seemingly bloated DIS machinery with its appetite for global intelligence gathering. ${ }^{21}$ On the intelligence side, PUSD was the FCO's central nexus. $^{22}$ It had been created in the late 1940s, bringing together a number of planning and controlling functions within the Foreign Office. Hitherto, the Private Secretary to the Permanent Under Secretary had carried many of these functions more or less singlehanded. The best example of this was perhaps the ill-fated wartime incumbent, Peter Loxley, who had undertaken much intelligence co-ordination on behalf of his master, Alexander Cadogan. PUSD had also absorbed the Services Liaison Department which had served as a wartime interface between the diplomats and the JIC. It co-ordinated with SIS and ran a small group that oversaw special operations. After 1945, with the advent of regular imagery and sigint gathering missions by aircraft and submarines, PUSD also became the clearing-house to which MOD turned for political approval for each specific operation. Depending on their sensitivity, these requests were reviewed at the official, ministerial or even prime ministerial level. ${ }^{23}$

In July 1975, PUSD were clearly anxious to prevent any of the adverse comment on the sprawling intelligence activities of DIS from finding its way into the FCO's formal feedback and reaching the ears of the MOD. Tonkin was therefore at some pains to re-assure his diplomatic colleagues, informing them that the ongoing defence review would have a significant impact on MOD intelligence gathering, resulting in what he anticipated would be 
at least a $10 \%$ cutback. However, at the same time he encouraged his colleagues not to address this matter openly in the context of the review of the management of MOD, suggesting that instead it this would probably be dealt with through 'other channels'. In the event its appears that none of the above negative FCO commentary on DIS reached the ears of the MOD.

More importantly, Tonkin offered a lengthy apologia for MOD's interest in intelligence and analysis concerning areas of the world where the services were never likely to be deployed. This defence was couched almost entirely in terms of the high value of the Anglo-American intelligence relationship. He argued that the efforts of DIS helped to offset an intelligence imbalance in terms of what the UK offered and what it received from the US. ${ }^{24}$ He also explained that while the necessity of UK defence cutbacks had been reluctantly accepted by Washington, the Americans had nevertheless urged that the UK intelligence effort should not be trimmed, as they regarded this contribution as pre-eminent. Finally and perhaps most intriguingly, Tonkin offered the observation that the UK-US intelligence relationship was about rather more than intelligence. It had now come to constitute some of the wider substance of the mainstream political relationship and offered London a remarkable window on political thinking in Washington. It is rare for officials to cast up these sorts of generalised evaluations of liaison and the presence of Tonkin in PUSD suggests that it was probably authoritative. Accordingly, his minute may be of general interest to readers of this journal and, rather than attempting to offer a lengthy summary of the document, it it perhaps best to reproduce it here in appendix. ${ }^{25}$ 


\author{
Mr Jackson (Defence Dept) \\ Cc: $M r$ Sykes \\ Mr Cable \\ Mr Thompson c.r.
}

MANAGEMENT REVIEW OF MOD HQ

1. Your minute [fo.8] of 26 August.

2. PUSD have one general comment to make, relating to paragraph 2 of $\mathrm{Mr}$ Cable's minute [fo.6] of $31 \mathrm{July}$; and one specific comment relating to PUSD's experience in liaison with the MOD during the past two years.

3. Our general comment is that I am sure that $\mathrm{Mr}$ Cable is absolutely right when he says that too much effort is still being devoted to intelligence and analysis concerning areas of the world where the British Armed Forces are never likely to play a significant part. Scarcely a week passes without PUSD being conscious of some alleged intelligence requirement prompted by the Defence Intelligence Staff which seems to be either unnecessary or ill-advised. Nonetheless, considerable progress has been made in recent years, particularly during the last 18 months, in persuading the DIS to be more reasonable. The Defence Review itself should have a significant impact on MOD intelligence-gathering. Our own administration have had some success, through the Cabinet office, in reducing the establishment of MOD posts abroad devoted to intelligence - notably in washington. The DIS itself 
has been subject to fairly rigorous inspection; and as a result of the current economy review of Government expenditure, which will have its impact on the intelligence agencies, at least another $10 \%$ of the DIS budget will be cut. In short, I think you can take it that there is bound to be some significant trimming of the DIS Vote which will be reflected in a reduction in MOD intelligence-gathering and analysis. I would not myself think that this aspect should be considered in the context of the present Management Review of MOD HQ and I feel sure the MOD would resist this on the grounds that it is being dealt with on other channels.

4. I would like however to offer some apology for the MOD's interest in intelligence and analysis concerning areas of the world where British Armed Forces are never likely to play a significant part. As is generally known in the FCO (but not by the press or Parliament), there is a long-standing intelligence relationship with the United States dating from the second World War. The balance of advantage in this intelligence exchange is overwhelmingly in our favour. If the Americans were to withdraw their contribution, we would lose much extremely useful intelligence, including certain very important lines of intelligence which only the Americans can supply. Nonetheless, the Americans need us, both for the intrinsic value of our contribution especially our assessments - but also because (we know) they find it extremely useful, particularly in times of crisis, to have a sounding board against which they can judge their own assessments. Their relationship with us in the intelligence field is a quite unique; it is of a kind which they enjoy with no other partner.

5. The intelligence exchange with the Americans is perhaps the last bastion of the "special relationship". But it is still very active and very effective. This is accepted by those of influence in the American Administration and I believe the relationship pays us very useful dividends in the political sphere. The relationship gives us an entrée to American political thinking in a way that no other country is able benefit. Visitors to Washington over the past 18 months have all come back with a message something on the following lines: 
"We know that you in Britain spend much more on intelligence than is strictly justified by British defence interests. However, we in the United States find your contribution to intelligence of very great value and we very much hope that, whatever economies you may feel bound to make, you will not let your intelligence contribution diminish. We would regard this as a serious loss."

6. What this all means is that I think it would be wrong for the FCO to insist that the effort devoted by the MOD to intelligence and analysis should only concern areas of the world where the British Armed Forces are likely to play a significant part. There are very real British interests, more of a political than an intelligence nature, which make it most desirable that our contribution to the AngloAmerican intelligence exchange should not diminish significantly. While certain economies in the MOD in this sphere may be desirable, it is most important that we should not forget the political benefits of the Anglo-American intelligence exchange. I suspect that this aspect is insufficiently understood within the FCO generally - and certainly by the press and by parliament, for obvious reasons. If anything, it is partly the fault of PUSD for not having drawn the message sufficiently to the attention of Heads of Departments and Under-Secretaries.

7. Now for the specific comment. PUSD's dealings with the MOD have generally been smooth and harmonious, though we would welcome a greater flexibility and greater willingness on the part of our contacts to take responsibility. In times of crisis - for example, during the Turkish invasion of Cyprus last year - we found that the civilian component of the MOD continued to work only normal office hours, leaving the crisis management arrangements to service personnel. As a result, on at least one occasion, PUSD, who should have been consulted about certain MOD intelligence-gathering operations agreed at short notice after normal hours, found at they had been short-circuited because the service operational staff in the MOD did not understand PUSD's function and sought clearance for certain very sensitive RAF operations with the [FCO] Emergency Unit. Although PUSD advice was available throughout (a PUSD officer attached to the Emergency Unit on the night shift), decision were taken at the desk officer level which could have had 
potentially serious consequences. We think it most important that the MOD civilian-staff policy department should operate, as PUSD do, on a 24 hours basis during times of crisis or tension.

\section{DTonkin}

D Tonkin

29 August 1975

PUSD

$1 \quad$ This research was generously supported by an award from the British Academy. I am indebted to Matthew Jones and Adam Svendsen for their comments. Errors remain the responsibility of the author.

2 C.M. Andrew, 'Anglo-American-Soviet Intelligence Relations', in A. Lane and H. Temperley, The Rise and Fall of the Grand Alliance, 1941-45 (London: Macmillan, 1995), p.129; D. Reynolds, 'A "special relationship"? America, Britain and the international order since the Second World War', International Affairs, 62, 1 (Winter 1985), p.11; J. Dumbrell, A Special Relationship: Anglo-American Relations in the Cold War and After (London: Palgrave, 2001), pp.124-5.

3 The last helicopter took off from the American Embassy in Saigon on 30 April 1975. $4 \quad$ Scott Shane, 'US Reclassifies Many Documents in Secret Review', New York Times, 21 February 2006.

$5 \quad$ On FOIA, the MoD and DFID had been helpful in early 2005, while the Home Office and the Treasury are, seemingly, the bad boys of Whitehall, Freedom of Information Act 2000 Statistics on Implementation in Central Government Q1: January - March 2005 available at http://www.dca.gov.uk/foi/stats-janmar05.pdf accessed 2 April 2006.

$6 \quad$ Unfortunately, during the late 1990s, the MoD's archivists moved locations and latterly discovered asbestos contamination in their sensitive file store. Most of the material that the MoD had not yet declassified had to be set aside for decontamination. An estimated 63,000 files are involved. Although this problem is being addressed with commendable vigour, fewer MoD files are currently becoming available and so one of the more successful avenues for intelligence research in the UK archives for the period after 1970 has temporarily diminished, Ben Fenton, 'Asbestos Threatens British Cold War Records', The Daily Telegraph, 25 October 2004.

7 The most useful analysis of this period is contained in J.W Young, Labour Governments 1964-70, Volume 2: International Policy (Manchester: Manchester University Press, 2003).

$8 \quad$ Memo from the Directorate of Intelligence and Research, DoS, to Risk, 'What Now for Britain? Wilson's Visit and Britain's Future', REU-11, 7 Feb. 1968, Philip M. Kaiser papers, Box 8, Harry S. Truman Library, Independence, Missouri. 
9 Cary (MOD) to Brimelow (FCO), PUS/75/303, 11 July 1975, fo.1, DP1/12, FCO 46/1246, PRO; Brimelow (FCO) to Cary (MOD), 20 July 1975, fo.5, ibid.

10 Cable enumerated the six MOD hierarchies as the three services, the civilian staff, the scientists and the defence sales organisation.

11 Cable minute, 'Management Review of MOD HQ', 31 July 1975, fo.6, DP1/12, FCO 46/1246, PRO. The connections between withdrawal East of Suez and a Europe-focused foreign policy were being made by the diplomats as early as 1968, see for example C(68)42, 'Foreign Policy', Cabinet Memorandum by George Brown, 23 Feb 1968, document no.153 in S.R. Ashton and Wm R Louis (eds.), East of Suez and the Commonwealth 1964-71: Part II Europe, Rhodesia, Commonwealth (London: The Stationery Office, 2004), pp.73-80.

12 A.J. Hunter minute, 'Management Review of MOD HQ', 3 September 1975, fo.12A, DP1/12, ibid.

13 MOD seem to have had its own Directorate of Economic Intelligence. Minute by Defence Dept, 'Illustrations for use in Discussions with the Review Team', 1 October 1975, DP1/12, ibid. 14 D.J. Wright minute, 28 August 1975, fo.8B, DP1/12, ibid.

15 S. Lambert minute, 28 August 1975, fo.8B, DP1/12, ibid.

16 This is briefly explored in R. J. Aldrich, 'British Intelligence, Security and Western Cooperation in Cold War Germany: The Ostpolitik Years', in Beatrice de Graaf, Ben de Jong, Wies Platje (eds.) German-Dutch Intelligence Relations (Amsterdam: Uitgeverij Het Spinhuis, 2006).

17 D. Beattie, 'Management Review of MOD', 1 September 1975, DP1/12, FCO 46/1246, PRO.

18 Percy Cradock, Know Your Enemy: How the Joint Intelligence Committee Saw the World (London: John Murray, 2002) pp.261-3.

19 M. Herman, 'Intelligence and the Iraq Threat: British Joint Intelligence After Butler', RUSI Journal, Vol.149, No.4 (August 2004):18-24; A. Danchev (ed.), The Franks Report: Falklands Islands Review (London: Pimlico, 1992), pp.85-6.

20 Butler Report, Review of Intelligence on Weapons of Mass Destruction, HC 898, 2004, p.144, paras 598-601. On the connections between Franks and Butler see Eunan O'Halpin, 'British Intelligence and Case for Confronting Iraq: Evidence from the Butler and Hutton Reports', Irish Studies in International Affairs, Vol. 16 (2005), pp.95-7.

21 Derek Tonkin remained with PUSD until 1976. Thereafter he served in the recently opened UK Embassy in East Berlin, before becoming UK Ambassador in Vietnam in 1980.

$22 \quad$ On PUSD see FCO Historians, Records of the Permanent Under-Secretary's Department: Liaison between the Foreign Office and British Secret Intelligence, 1873-1939 (London: FCO, 2005), p.5; P. Davies, MI6 and the Machinery of Spying (London Frank Cass, 2004), pp.222-2.

${ }_{23}$ Although PUSD initially absorbed some service liaison and planning functions, the FCO eventually sprouted fresh Defence and Planning Departments.

$24 \quad$ In the mid-1970s this was especially apparent with the onset of a new generation of US sigint satellites with a phenomenal collection capacity which taxed the analytical capabilities of the USA and its closer allies.

25 D. Tonkin minute to E. Jackson (Defence Department), 'Management Review of MOD HQ', 29 August 1975, fo.6B, FCO 46/1246, PRO. This minute is reproduced in full here. 